\title{
Valon ja melun vaikutus nautojen hyvinvointiin ja kasvuun
}

\author{
Christa Nylander ${ }^{1)}$, Suvi Pekkanen ${ }^{1)}$, Risto Kauppinen ${ }^{1)}$, Arto Huuskonen ${ }^{2)}$, Jaakko Mononen ${ }^{3)}$, \\ Juha Alatalo ${ }^{4)}$ \\ 1) Pohjois-Savon ammattikorkeakoulu, Maaseutuopetus, 74100 Iisalmi, etunimi.sukunimi@ pspt.fi \\ ${ }^{2)}$ MTT/Pohjois-Pohjanmaan tutkimusasema, 92400 Ruukki, arto.huuskonen@mtt.fi \\ ${ }^{3)}$ Soveltavan Biotekniikan Instituutti/Kuopion yliopisto, PL 1627, 70211 Kuopio, \\ jaakko.mononen@uku.fi \\ ${ }^{4)}$ A-Tuottajat Oy, PL 910,60061 Atria, juha.alatalo@a-tuottajat.fi
}

\section{Johdanto}

Nautakarjatalouden tuotantoyksiköiden koko on kasvanut paljolti siitä syystä, että suuremmat yksiköt mahdollistavat paremman kustannustehokkuuden. Tehokkuuteen pyritään lisäämällä esimerkiksi koneiden ja automaation käyttöä eläinten ruokinnassa ja hoidossa. Tuotantoyksiköiden toiminnallisten vaatimusten johdosta erilaisten melutekijöiden määrä eläinten kasvatusympäristössä on lisääntynyt. Myös valaistuksen merkitys on korostunut. Negatiivisten vaikutusten välttämiseksi suunnittelussa on tarpeen huomioida valon ja melun vaikutus eläimiin.

Tässä kirjallisuustutkimuksessa selvitettiin, aikaisempiin tutkimuksiin nojautuen, valon ja melun suoria ja välillisiä vaikutuksia naudan hyvinvointiin ja kasvuun. Tutkimus käynnistettiin ATuottajat Oy:n "Rakentava Kumppanuus" - hankkeen toimesta.

\section{Valo}

Eläinsuojien hyvä valaistus on tärkeä, jotta saavutetaan sellainen työympäristö, jossa työskentely on tehokasta, turvallista ja mukavaa ja joka täyttää eläinten hyvinvoinnille välttämättömän valon tarpeen. Karjasuojien yleisvalaistuksen voimakkuudeksi suositellaan noin 100 luksia. Valo on riittävä, kun valaistuksessa käytetään tehoa $4-6$ wattia lattianeliömetri (Maatilarakennusten suunniteluohjeet MRO C3 1993).

Jotta eläin pystyy näkemään, täytyy valoa olla niin paljon, että se läpäisee silmän ja kohteen kuva muodostuu verkkokalvolle. Valo aiheuttaa erilaisia kemiallisia muutoksia eläimen silmän kudoksissa verkkokalvon rakenteesta riippuen. Jos verkkokalvo sisältää ns. tappeja, eläin kykenee näkemään värejä. Naudan verkkokalvolla on tappeja ja se pystyy havaitsemaan punaisen, keltaisen, oranssin ja vihreän. Sinistä väriä se ei kykene tunnistamaan, joten sen reaktion esimerkiksi sinisiin työvaatteisiin voi olettaa olevan varsin neutraali (Thines \& Soffie 1977).

Oikeanlaisella valaistuksella on todettu olevan vaikutusta nautojen lisääntymiseen, kasvuun ja maitotuotokseen. Lypsylehmillä tehdyt tutkimukset osoittavat, että $16-18$ tunnin valoisa aika vuorokaudessa nostaa maitotuotosta $5-16 \%$ verrattuna tuotokseen lehmillä, joilla valoisan ajan pituus oli 13,5 tuntia tai vähemmän (Peters 1994). USA:ssa ja Kanadassa tehdyissä kokeissa on todettu, että navettaan kannattaa talven aikana järjestää pitkän päivän valaistus eli $16-18$ tuntia valoa ja yöllä 6 - 8 tuntia pimeää. Maidon koostumuksessa ei ole havaittu eroja, mutta tuotos on lisääntynyt keskimäärin $2,5 \mathrm{~kg} / \mathrm{pv}$. Etenkin hiehoilla lisävalaistuksen on todettu lisäävän kasvua ja tehostavan maitorauhasen kehittymistä (Tucker \& Ringer 1982, Zinn ym. 1989).

Päivän pituus näyttää vaikuttavan nimenomaan hiehojen kasvuun. Hiehoilla, joita altistettiin 16 tunnin valojaksolle päivittäin, oli $10-15$ prosenttia suurempi päiväkasvu kuin $9-12$ tuntia valoa saaneilla hiehoilla. Ne söivät enemmän ja lisäksi rehun hyötysuhde oli parempi kuin vähemmän valoa saaneella ryhmällä (Tucker \& Ringer 1982). Valaistuksen voimakkuus on ollut 100 - 300 lx silmien tasolta mitattuna (Peters ym. 1978, Petitclerc ym. 1983, Zinn ym. 1988).

Hiehojen parempi kasvu talvella pitkän päivän olosuhteissa ja parantunut rehuhyötysuhde saattavat johtua siitä, että rasvan kertyminen ruhoon vähenee. Rasva sisältää energiaa noin 39 $\mathrm{MJ} / \mathrm{kg}$ ja proteiini noin $23 \mathrm{MJ} / \mathrm{kg}$. Talvella pitkän päivän olosuhteissa rasvan muodostuminen on ollut selvästi vähäisempää kuin lyhyen päiän olosuhteissa. Kevättä kohden mentäessä ero pienenee, koska rasvan kasvu on nopeampaa pitkän päivän olosuhteissa kasvaneilla. Aikaisempi 
valohistoria näyttää vaikuttavan hiehojen myöhempään kasvuun. Aikavälillä syksystä kevääseen pitkän päivän ja lyhyen päivän olosuhteissa kasvatettujen hiehojen rasvoittumisessa ei ole eroja (Phillips ym. 1997).

On kuitenkin mahdollista, että hiehojen päiväkasvua ja rehunkäyttökykyä voitaisiin parantaa ja ruhon rasvaisuutta vähentää lisäämällä päivän pituutta loppusyksyllä ja talvella. Valon vaikutusta voidaan käyttää suunniteltaessa hiehojen teurastusajankohtaa. Päivittäisen valoisan ajan lisääminen silloin kun luonnonvaloa on vuodenajasta johtuen vähän, saattaisi antaa mahdollisuuden kasvattaa lihahiehoja tarvittaessa korkeampiin teuraspainoihin.

Veren korkea prolaktiinin ja insuliinin kaltaisen kasvutekijän (IGF-I) määrä osoittavat, että valon aikaansaamat kasvunopeuden muutokset johtuvat myös hormonaalisista muutoksista. Nopeilla kasvuluvuilla ja korkealla prolaktiinipitoisuudella on osoitettu olevan yhteys ja esimerkiksi poroilla tehdyissä tutkimuksissa veren IGF-I määrän kohoamisella ja kasvun nopeutumisella on selvä yhteys (Suttie ym. 1991). Sen sijaan valaistuksella ei ole vaikutusta veren kasvuhormonin (somatotropiini) määrään (Kendall ym. 2003).

Pitkän päivän valojaksossa myös lehmävasikoiden kasvun on todettu nopeutuvan. Kasvun paraneminen saattaa liittyä myös eläinten parantuneeseen terveyteen päivän pituuden kasvaessa. Veren immunoglobuliinien (IgG) on todettu kohoavan päivän pituuden kasvaessa (Phillips ym. 1998).

Sonnien kasvuun päivän pituuden lisäämisellä ei ole ollut vaikutusta. Tämä saattaa johtua siitä, että valaistuksen vaikutukset ovat kytkeytyneet eläimen sukupuoleen. Toisaalta päivän pituutta koskevissa tutkimuksissa sonnit on teurastettu melko aikaisessa kasvuvaiheessa, joten se on osaltaan saattanut vaikuttaa tuloksiin.

Päivän piteneminen keväällä luonnollisissa valaistusolosuhteissa saattaa kiihdyttää sonnien kasvua. Tammikuussa kasvattamoon siirretyt sonnivasikat olivat keskimäärin 23 kiloa painavampia 350 päivän iässä kuin kesäkuussa kasvattamoon siirretyt vasikat. Kasvun paranemisen mekanismia ei toistaiseksi tiedetä (Aharoni ym. 1997). Kasvun paraneminen saattaa olla osittain ruokinnasta johtuvaa. Säilörehun käymislaatu on parempi syksyllä kuin keväällä ja sonnit syövät vapaalla ruokinnalla säilörehua enemmän syksyllä kuin keväällä. Keväällä vähentynyt säilörehun syönti korvautuu todennäköisesti väkirehulla.

Pitkät päivät nostavat kasvulukuja ja aikaistavat puberteettia. Pitkän päivän olosuhteissa hiehot alkoivat näyttää sukukypsyyttä aikaisemmin kuin lyhyen päivän olosuhteissa Hiehot, joita on kasvatettu 16 tunnin päivittäisessä valaistuksessa, ovat saavuttaneet sukukypsyyden kuukautta aikaisemmin kuin hiehot, joilla on ollut 8 tunnin valoisa aika (Phillips ym. 1997).

Naudat tarvitsevat myös pimeän jakson. Jatkuvan, yhtäjaksoisen valaistuksen ei ole todettu lisäävän päivittäistä kasvua. Tämä saattaa johtua melatoniinin erityksen vähenemisestä (Tucker \& Ringer 1982). Melatoniini vaikuttaa useiden hormonien eritykseen ja muutokset valaistuksessa aiheuttavat fysiologisia muutoksia kasvussa, maidonerityksessä ja lisääntymisessä. Melatoniinisynteesi käynnistyy pimeän aikana ja estyy valon vaikutuksesta. Syksyllä päivän pituuden lyhentyessä melatoniini saa luonnon eläimillä aikaan talvikarvan vaihdon ja keväällä vastaavasti karvan vaihtuu ohuempaan. Myös naudalla karvan kasvu muuttuu syksyllä ja karvapeite on talvella paksumpi. Naudalla karvan kasvu liittyy kuitenkin ruokintaan ja rehun hyväksikäyttöön ja voimakkaalla ruokinnalla karvapeitteessä ei juuri tapahdu muutoksia.

\section{Melu}

Melulla tarkoitetaan tarpeettoman haitallista ja kovaa ääntä. Eläinsuojelulain mukaan nautojen pitopaikassa ei saa esiintyä jtkuvaa, eläintä häiritsevää tai sille haittaa aiheuttavaa melua. Eläintiloissa melua aiheuttavat mm. kalusteet, laitteet ja eläinten oma ääntely. Naudat eivät saa jatkuvasti olla alttiina $65 \mathrm{~dB}(\mathrm{~A})$ ylittävälle melulle.

Äänen kuultavuus riippuu sen värähtelytaajuudesta ja voimakkuudesta. Värähtelytaajuus mitataan hertseinä $(\mathrm{Hz})$ ja voimakkuus desibeleinä $(\mathrm{dBA})$. Desibeliasteikko on logaritminen, jolloin yhden desibelin ero asteikolla merkitsee kolminkertaista eroa äänenvoimakkuudessa. Fysiologian lakien mukaan joka $6 \mathrm{~dB}$ muutos kaksinkertaistaa äänen voimakkuustason. Käytännössä kuuloelimistö kykenee hahmottamaan joka $10 \mathrm{~dB}(\mathrm{~A})$ muutos, jolloin äänen voimakkuus aina kaksinkertaistuu eli $60 \mathrm{~dB}$ äänen voimakkuuden taso on kaksinkertainen 50 $\mathrm{dB}(\mathrm{A})$ äänen voimakkuuteen. Äänen kovuus korreloi ääniaallon värähdyslaajuuden kanssa. Mitä suurempi värähtely, sitä kovempi ääni. 
Nauta kuulee sellaisia äänen taajuuksia ja niin heikkoja äänen voimakkuuksia että monet muut eläimet ja esimerkiksi ihminen eivät niitä kykene havaitsemaan. Ihmisen kuuloalue on $32 \mathrm{~Hz}$ ja $32 \mathrm{kHz}$ välillä ja kuulokynnys on $-10 \mathrm{~dB}(\mathrm{~A})$. Naudan kuuloalue on $23 \mathrm{~Hz}-35 \mathrm{kHz}$ välillä ja parhaiten nauta kuulee äänentaajuuden ollessa $8 \mathrm{kHz}$, jolloin se pystyy reagoimaan vain -11 dB(A) äänenvoimakkuuteen (Heffner \& Heffner 1983). Hevosen kuuloalue on kapeampi (55 Hz $45 \mathrm{kHz})$ ja kuuloherkkyys huonompi kuin naudalla $(2 \mathrm{kHz}, 7 \mathrm{dBA})$. Naudan kuuloalue on korkeita taajuuksia lukuun ottamatta jopa parempi kuin koirilla $(67 \mathrm{~Hz}-45 \mathrm{kHz})$. Koirien kuuloherkkyys on parhaimillaan $8 \mathrm{kHz}$ äänentaajuudella, jolloin ne reagoivat $3 \mathrm{~dB}(\mathrm{~A})$ voimakkuuteen (Heffner \& Heffner 1983).

Voimakas, äkillinen tai sisällytyksetön melu on eläimelle stressaavaa (Rajala 1990). Voimakas melu saattaa heikentää kasvua ja aiheuttaa lisääntymishäiriöitä. Prolaktiinin ja somatotropiinin (kasvuhormonin) erityksen on todettu olevan erityisen herkkiä stressin vaikutukselle (Moberg 2000). Waynert ym. (1998) tutkivat erilaisten melulähteiden vaikutusta nautoihin. Ihmisääni ( $86 \mathrm{dBA})$ ja metallin kalahdukset $(85 \mathrm{dBA})$ aiheuttivat stressiä eläimissä. Normaalissa keskustelussa äänenvoimakkuus on noin $60 \mathrm{~dB}$.

Lehmillä $40-60 \mathrm{~dB}(\mathrm{~A})$ äänenvoimakkuus aiheutti levottomuutta, lepoajan lyhentymistä ja syöntihaluttomuutta (Hauptman 1970 ref. Nieminen 1976). Algers \& Ekesbo ref. Muller (1977) pitävät vuorokauden pitkäaikaisena suositeltavana keskiarvona $45 \mathrm{~dB}(\mathrm{~A})$ äänitasoa eläinsuojissa.

Vilelijän työympäristöä lypsykarjatiloilla käsittelevässä Työterveyslaitoksen tutkimuksessa (Louhelainen ym. 1983) navetoiden melutasot olivat 55 - $85 \mathrm{~dB}(\mathrm{~A})$. Lypsykarjatilan työympäristöä käsittelevässä tutkimuksessa (Louhelainen ym. 1995) navetoiden melutasot olivat $28-75 \mathrm{~dB}(\mathrm{~A})$. Keskeisimmiksi melulähteiksi osoittautuivat erilaiset koneet ja laitteet.

Se, että melua ei välttämättä huomioida elä inten käsittelyssä saattaa johtua siitä, että melun katsotaan kuuluvan työhön ja melu on osa työympäristöä. Eläinten käsittelyyn liittyvä melu ja sen aiheuttama pelon tunne eläimissä saattaa näin jäädä huomioimatta. Ärsyke, joka on voimakas, uusi tai tapahtuu yhtäkkiä aiheuttaa pelkoa. Pelko on yleinen tunne, joka ohjaa eläintä välttämään saalistajia ja se aiheuttaa muutoksia sekä käyttäytymisen että fysiologiassa. Jotkut äänet saattavat ärsyttää nautoja enemmän kuin hoitajia, koska nauta kuulee matalampia ja korkeampia taajuuksia kuin hoitaja. Ihmisen ääni on eläimille selvästi stressaavampaa kuin karsina - aitojen ja metallin kolina. Tämä saattaa johtua siitä, että naudat voivat yhdistää äänet johonkin epämiellyttävään tapahtumaan ja se lisää pelkoa. Käsittelystä johtuva melu ja siitä aiheutuva pelko- tai stressitilanne voi vaikuttaa kasvuun negatiivisesti. Prolaktiinin ja kasvuhormonin erityksen on todettu olevan erityisen herkkiä stressin vaikutukselle.

Melua ja erityisesti äkillistä, voimakasta melua on syytä pyrkiä välttämään, koska on epätodennäköistä, että naudat kykenisivät mukautumaan ärsyttävään ja pelkoa herättävään meluun. Koneiden ja laitteiden aiheuttamaan meluun voidaan vaikuttaa tuote- ja rakennussuunnittelulla. Eläinten aiheuttamaan meluun ei juurikaan voida vaikuttaa.

\section{Kirjallisuus}

Aharoni, Y., Brosh, A., Holzer, Z. 1997. Photoperiod effect on live-weight gain of bull calves. Animal Science 65: 165 - 171.

Heffner, R.S., Heffner, H.E. 1983. Hearing in Large Mammals: Horses (Equus caballus) and cattle (Bos Taurus). Behavioral Neuroscience, Vol. 97, 2:299-309.

Heffner, H.E. 1983. Hearing in Large and Small Dogs: Absolute Thresholds and Size of the Tympanic Membrane. Behavioral Neuroscience, Vol. 97, 2:310-318.

Kendall, P.E., Auchtung, T.L., Swanson, K.S., Radcliff, R.P., Lucy, M.C., Drackley, J.K., Dahl, G.E. 2003. Effect of photoperiod on hepatic growth hormone receptor 1A expression in steer calves. Journal of Animal Science 81: 1440 - 1446.

Louhelainen, K., Kangas, J., Sorainen, E., Husman, K., Kalliokoski, P. 1983. Viljelijän työympäristö. Tutkimuksia 202. Työterveyslaitos, Helsinki.

Louhelainen, K. 1995. Työympäristö nykyaikaisella lypsykarjatilalla (Toim. Kyösti Louhelainen). Maatalousyrittäjien eläkelaitoksen julkaisuja 1/96.

Maa- ja metsätalousministeriö. 1993. Maatilarakennusten suunniteluohjeet MRO C3.

Moberg, G.P., Mench, J.A. 2000. The Biology of Animal Stress. Basic Principles and Implications for Animal Welfare. CABI Publishing. 5-8. 
Muller, W. 1987. Effects of excessive noise on man and animals. In: Starauch, D. Animal production and environmental health. World Animal Science. B 6. ss. 40 - 47.

Nieminen, L., Karhunen, J., Mykkänen, U., Pyykkönen, M., Saloniemi, H. 1975. Parsinavettatutkimus 1973 - 1975. Vakolan tiedote 24/75.

Peters, R.R., Chapin, L.T., Leining, K.B., Tucker, H.A. 1978. Supplemental lightning stimulates Growth and Lactation in Cattle. Science vol. 199.

Peters, R.R. 1994. Photo period and management of dairy cows: A practical review. In: Dairy Systems for the $21^{\text {st }}$ Century. Proceedings of the Third int. Dairy Housing Conf. ASAE, St. Joseph, MI. 662 - 666.

Petitlerc, D., Chapin, L.T., Emery, R.S., Tucker, H.A. 1983. Body growth, growth hormone, prolactin and puberty response to photoperiod and plane of nutrition in Holstein heifers. Journal of Animal Science 57:892-898.

Phillips, C.J.P., Johnson, P.N., Arab, T.M. 1997. The effect of supplementary light during winter on the growth, body composition and behaviour of steers and heifers. Animal Science 65: $173-181$.

Phillips, C.J.C., Schofield, S.A. 1998. The effect of supplementary light on the production and behaviour of dairy cows. Animal Production 48:293-303.

Suttie, J.M., White, R.G., Breier, B.H., Gluckman, P.D. 1991. Photoperiod associated chenges in insulin-like growth factor-1 in reindeer. Endocrinology 129:679- 682

Thines, G., Soffie, M 1977. Preliminary experiments on colour vision in cattle. British Veterinary Journal 133(1):97-98.

Tucker, H.A., Ringer, R.K. 1982. Controlled photoperiodic environments for food animals. Science vol. 216.

Zinn, S.A., Chapin, L.T., Tucker, H.A. 1988. A Note on the effects of previous photoperiod exposure and gradual transitions of light intensity at dawn and dusk on growth in Holstein heifers. Animal Production 46:300-303.

Waynert, D.F., Stookey, J.M., Schwartzkopf-Genswein, K.S., Watts, J.M., Waltz, C.S. 1998. Theresponse of beef cattle to noise during handling. Applied Animal Behaviour Science 62:27-42. 